\title{
Environmental and morphological factors influencing predatory behaviour by invasive non-indigenous gammaridean species
}

\author{
Gerard van der Velde $\cdot$ Rob S. E. W. Leuven · Dirk Platvoet • \\ Karolina Bacela · Mark A. J. Huijbregts · Harrie W. M. Hendriks • \\ Dirk Kruijt
}

Received: 15 February 2008/Accepted: 8 January 2009/Published online: 25 June 2009

(C) The Author(s) 2009. This article is published with open access at Springerlink.com

\begin{abstract}
Predatory behaviour seems to be more frequent in invasive gammaridean species than in native ones. This results in the exclusion of other, mostly native gammaridean species and a change in benthic communities. The present study analysed the influence of environmental factors (water temperature) and morphological factors (sex, body parts involved in catching and holding prey) on the predatory behaviour of Dikerogammarus villosus. A diet study of invasive relatives of $D$. villosus showed that predation intensity is especially high in spring and summer, that is, at increasing and high temperatures. Experiments with $D$. villosus in climate rooms at various temperatures, using the native Gammarus fossarum as prey, showed that the average predation rate by both sexes gradually increased over the temperature range from 5 to $30^{\circ} \mathrm{C}$.
\end{abstract}

G. van der Velde $(\bowtie) \cdot$ D. Kruijt

Department of Animal Ecology and Ecophysiology, Institute for Wetland and Water Research, Radboud University Nijmegen, Heyendaalseweg 135, 6525 AJ

Nijmegen, The Netherlands

e-mail: g.vandervelde@science.ru.nl

G. van der Velde

National Natural History Museum Naturalis,

P.O. Box 9517, 2300 RA Leiden,

The Netherlands

R. S. E. W. Leuven - M. A. J. Huijbregts

Department of Environmental Science, Institute

for Wetland and Water Research, Radboud University

Nijmegen, Heyendaalseweg 135, 6525 AJ Nijmegen,

The Netherlands
Natural mortality during the experiments was negligible compared to losses due to predation. At each temperature, the predation rate by females was lower than that by males. Males showed a steep allometric growth of body parts involved in the process of catching and holding prey, compared to females at increasing body size in a number of measurements. This may explain the difference in predatory behaviour between males and females, which plays a role in intraguild predation a supposed mechanism for species displacement.

Keywords Species displacements . Predation - Dikerogammarus villosus . Invasive amphipods - Sex · Water temperature . Allometric growth $\cdot$ Seasonal effects

D. Platvoet

Zoological Museum, University of Amsterdam,

Mauritskade 57, 1092 AD Amsterdam,

The Netherlands

K. Bacela

Department of Invertebrate Zoology

and Hydrobiology, University of Lodz, Banacha 12/16, 90-237 Lodz, Poland

H. W. M. Hendriks

Department of Mathematics, Faculty of Science, Radboud University Nijmegen, Heyendaalseweg 135, 6525 AJ

Nijmegen, The Netherlands 


\section{Introduction}

Amphipods belong to the most successful invaders in fresh and brackish waters (Jazdzewski 1980; Holdich and Pöckl 2007). Their ability to reach very high densities means they can have a large impact on benthic communities and even ecosystems (Van der Velde et al. 2000, 2002, 2006; Haas et al. 2002; Van Riel et al. 2006). Gammaridean amphipods are considered to be detritivores (phyto-detritophages, detritophages), omnivores (phyto-zoophages, zoophytophages) or predators (zoophages) (Monakov 2003). During invasions, increased predation on other macroinvertebrates and fish by gammaridean species is sometimes recorded, for instance in the case of the invasion of the North American gammaridean Gammarus tigrinus in continental Europe (Schmitz 1960) and the invasion of Gammarus pulex in Ireland (Kelly et al. 2003, 2006).

During successful invasions by non-indigenous gammarideans, native gammaridean species often become reduced in abundance or are locally even completely replaced by the non-indigenous relatives. Such species displacements by invasive gammaridean species have been recorded on several occasions all over the world (Pinkster et al. 1977; Dick et al. 1993, 1995; Dick 1996; Dick and Platvoet 1996, 2000; Dermott et al. 1998; Jazdzewski and Konopacka 2000, 2002; Jazdzewski et al. 2002, 2004, 2005; MacNeil and Prenter 2000; Van der Velde et al. 2000, 2002; Van Overdijk et al. 2003; Kelly et al. 2003; MacNeil et al. 2004; Kelly and Dick 2005; Meyer et al. 2005; Grabowski et al. 2006, 2007; Felten et al. 2008a).

Intraguild predation (Polis et al. 1989) is considered to be one of the main factors determining such species replacement processes (Dick et al. 1993, 1995, 1999; Dick 1996; Dick and Platvoet 1996, 2000; Kinzler and Maier 2003). The replacement of native gammarideans by invasives could thus be caused by asymmetry in mutual predation (Kinzler and Maier 2003). However, interference competition for shelter can also play a role (Van Riel et al. 2006, 2007, 2009; Platvoet et al. 2009a). These processes are influenced by body size, while in the field, habitat heterogeneity is also important, as heterogeneous habitats provide refuges that may prevent total replacement (MacNeil et al. 2008; Grabowski et al. 2009; Kestrup and Ricciardi 2009; Piscart et al. 2009; Platvoet et al. 2009a; Van Riel et al. 2009).
Dikerogammarus villosus can be studied as a model species of an omnivorous gammaridean showing a high degree of predation on fish eggs, recently hatched fish (Casellato et al. 2007; Platvoet et al. 2009b), on relatives including their own juveniles well as on other macroinvertebrates (Dick et al. 2002). Marguillier et al. (1998) and Van der Velde et al. (2000) noticed that the Ponto-Caspian gammaridean species $D$. villosus, which has invaded the Rhine system since 1994/1995 through the MainDanube canal (Bij de Vaate et al. 2002), must act as a predator, in view of the high values of $\delta^{15} \mathrm{~N}$, which are similar to those measured in zoobenthivorous fish. Van der Velde et al. $(2000,2002)$ and Haas et al. (2002) noticed that the composition of the communities changed after the arrival of $D$. villosus, and densities of macroinvertebrates, including the nonindigenous $G$. tigrinus on the stones along the River Rhine, were also observed to decrease (Van Riel et al. 2006, 2009; Leuven et al. 2009). Dick and Platvoet (2000) noticed the disappearance of the native Gammarus duebeni along the stony shores of Lake IJsselmeer, as well as a decrease in G. tigrinus in this zone after the arrival of $D$. villosus (Platvoet et al. 2009a).

It is unknown which factors determine when invasive gammarideans become more or less predatory. Several factors are suspected to play a role, such as differences in morphology, morphological change, genetic change, size, sex, water temperature, the presence of abundant food, etc. The objective of the present study is to unravel the dominant environmental and morphological factors of the predatory behaviour of invasive gammaridean species. We focus on water temperature, including season, and sex including body size and development of body parts involved in predation.

\section{Materials and methods}

Seasonal share of animal food in the diet of non-native gammarideans

We analysed the diets of three non-indigenous gammarid species, viz. Pontogammarus robustoides, Dikerogammarus haemobaphes, and Gammarus roeseli. P. robustoides and D. haemobaphes originate from the Ponto-Caspian region and were sampled in 
the middle stretch of the Vistula River. G. roeseli originating from the Balkan was sampled in the upper part of the Notec River in Poland.

Gammarideans for the study were collected four times in 2005: in winter, spring, summer and autumn. Thirty adult individuals were taken at random from each sample, after which they were dissected and the gut contents were sealed in lactophenol on a microscopic slide. Qualitative and quantitative analyses were then done following Hynes (1950) and Hyslop (1980). Qualitative analysis was applied to all gut contents, while the quantitative analysis was done only on the stomach content, as hard-to-digest material could be overrepresented in an intestine. The amount of animal remnants (i.e. oligochaetes, chironomids, crustaceans, mayflies etc.) (Fig. 1a-e) in the stomach was estimated, and an index of importance (IOI) of this category of food in the gammarids' diet was calculated as follows:

$\mathrm{IOI}_{i}=100 \times \mathrm{HI}_{i} / \Sigma \mathrm{HI}$

where $\mathrm{HI}_{i}=\% F_{i}+\% V_{i}$

and $\% F_{i}$ is the share of individuals that had eaten food category $i ; \% V_{i}$ is the share of food category $i$ in the stomach contents volume. Differences in predation

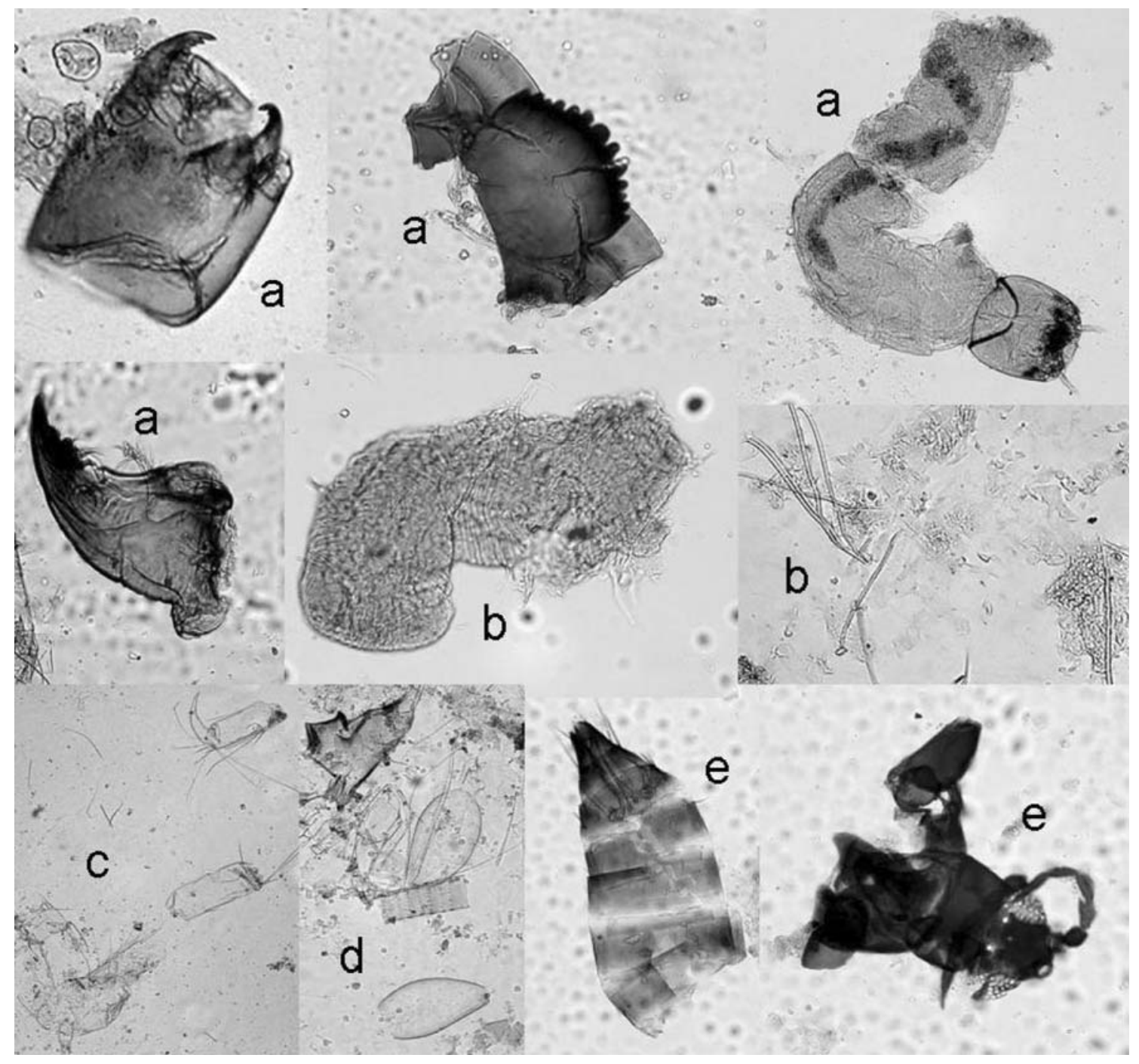

Fig. 1 Examples of animal remnants (a chironomids, b oligochaetes, c crustaceans, d mayflies and e other insects) found in gammaridean stomachs 
intensity of the various invasive gammaridean species were tested by a Kruskal-Wallis test.

Predation experiments in climate rooms

Predation by adult $D$. villosus (body length range 10 $20 \mathrm{~mm}$ ) on the native Gammarus fossarum (body length $5-15 \mathrm{~mm}$ ) was studied at six water temperatures, viz. $5,10,15,20,25$ and $30^{\circ} \mathrm{C}$, in climate rooms at a $50 \%$ light-dark regime, in order to assess the predation capabilities of $D$. villosus at various temperatures. The temperature range of $5-30^{\circ} \mathrm{C}$ should be tolerated by both species, as demonstrated by Wijnhoven et al. (2003a, b). We used 33 numbered plastic beakers per temperature, filled them with water $(115 \mathrm{ml})$ and added to each beaker one adult individual of $D$. villosus and one individual of G. fossarum. The duration of the experiments, which took place at constant temperature conditions, was 10 days. On each day during the experiment, the number of partly or totally consumed G. fossarum was recorded and they were replaced by new specimens from a stock. Remnants of G. fossarum were removed. Dead specimens of D. villosus were also recorded. Water was regularly refreshed when detritus particles became visible at the bottom of the beakers.

After each experiment at a particular temperature was finished, the individuals of $D$. villosus were separately preserved in $70 \%$ ethanol, in tubes labelled with the same number as the beakers, after which their sex was established by the presence of male genital papillae and female brood plates. Body length was assessed by measuring the length from the apex of the rostrum to the base of the telson.

As a control for the mortality of $G$. fossarum at the six temperatures, we used the 33 numbered plastic beakers also with one single $G$. fossarum each. This experiment was carried out once at each temperature, under light-dark conditions similar to those described above. No food was added to the beakers, and water was regularly renewed. Dead individuals were recorded daily over a period of 10 days.

Predation by the sexes related to temperature

The average predation rate of $G$. fossarum by the sexes of D. villosus (average number consumed per day), was related to the temperature using logistic regression, as the average predation rate varies between 0 and 1 day $^{-1}$ (Everitt and Dunn 2001):

$\ln \left(\frac{p}{1-p}\right)=a \cdot \mathrm{TEMP}+b$

where $p$ is the average predation rate of G. fossarum by $D$. villosus $\left(\mathrm{day}^{-1}\right)$, TEMP is the environmental temperature $\left({ }^{\circ} \mathrm{C}\right), a$ the slope and $b$ the intercept of the regression equation. The regression equation was optimized using a linear least squares fit to find appropriate values for the slope $(a)$ and intercept $(b)$. This was done for males and females, respectively, with $N=14-24$ for females and $N=8-15$ for males for each temperature.

Morphological measurements on sexes of $D$. villosus

The antennae, in particular the well-developed second antennae, in combination with the pereiopods and mouthparts, play a major role in gathering and processing food (Platvoet et al. 2009b). This means that these body parts may show morphological adaptations to a more predatory life style in $D$. villosus. We therefore studied the allometric growth of these body parts. A population of D. villosus in Lake Gouwzee (The Netherlands) was sampled and the sample transferred to $70 \%$ alcohol. Random samples of 10 males and 10 females were taken by placing them on a grid and using a random table. First the body lengths of the selected specimens were determined (see above), by means of a camera lucida, a piece of string and a scale fitted with an Olympus glass micro-measure. The piece of string was fitted around the contours of the dorsum of the specimens and then stretched out on the scale. The same method was used to measure the length of both first and second antennae. The width of the first peduncular article of antenna 1 was measured with the camera lucida and callipers. The width of the fourth peduncular article of the second antennae, the length of the basal body of the left mandible and the lengths of the propodi of pereiopods 1 and 2 (gnathopods 1 and 2) were determined in a similar way, at an accuracy of $0.1 \mathrm{~mm}$ (Fig. 2). The mandibles were dissected and mounted on a slide in glycerine. 
Fig. 2 Measurements on body parts of Dikerogammarus villosus involved in feeding: antennae 1 and 2, gnathopods 1 and 2 and mandible. Double arrows indicate measurements
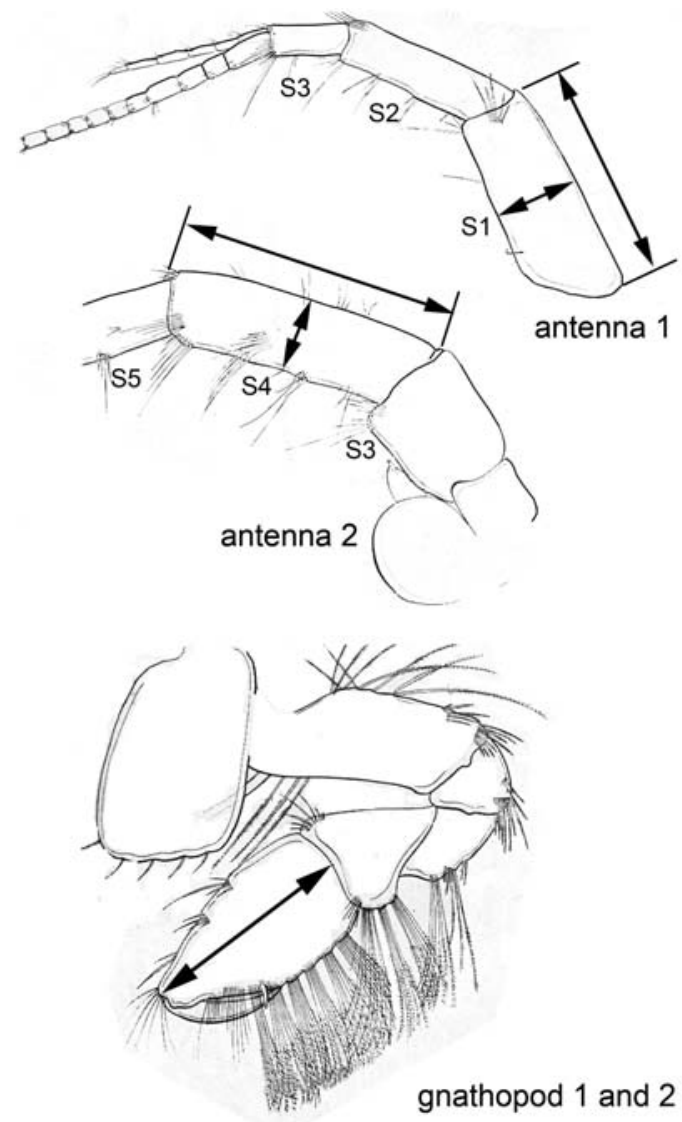

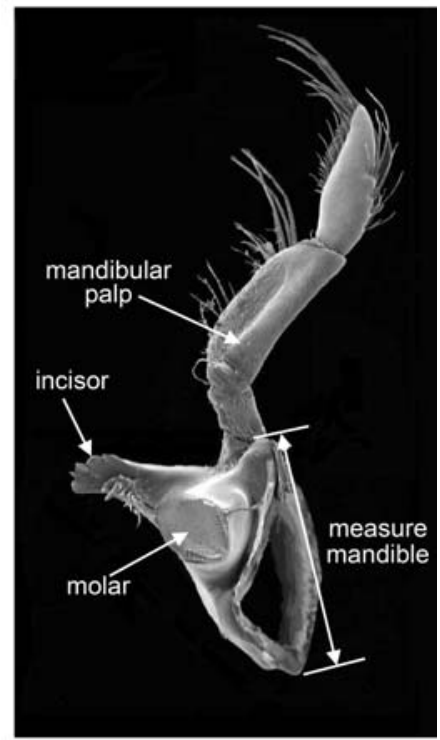

mandible

gnathopod 1 and 2

Allometric regression

Allometry means the disproportionate development (in terms of size) of some structure in relation to the rest of the body. Allometric relations for a number of morphological characteristics were derived via linear regression on the basis of the body length of males and females, respectively:

$C_{j, i}=a_{j, i} \cdot \mathrm{BL}_{i}+b_{j, i}$

where $C_{j, i}$ is morphological characteristic $j$ of gender $i, \mathrm{BL}_{i}$ the body length of gender $i, a$ the slope and $b$ the intercept of the regression equation for morphological characteristic $j$ of gender $i$. The regression equation was optimized using a linear least squares fit to find appropriate values for the slope $(a)$ and intercept $(b)$. For each morphological characteristic, we analysed whether the slopes of the allometric regressions differed significantly between males and females.

\section{Results}

Seasonal changes in animal food in the diet of non-native gammarideans

Gut contents analysis of the non-indigenous gammarids studied showed that predation intensity increased with higher temperatures. In the case of $P$. robustoides and D. haemobaphes, the predation intensity was lower in winter (Kruskal-Wallis test, $P=0.0012$ in both cases) than in spring and summer (Fig. 3).The largest amounts of animal remnants in the stomachs of Gammarus roeseli were found in summer (Kruskal-Wallis test, $P=0.0022$ ) (Fig. 3). 

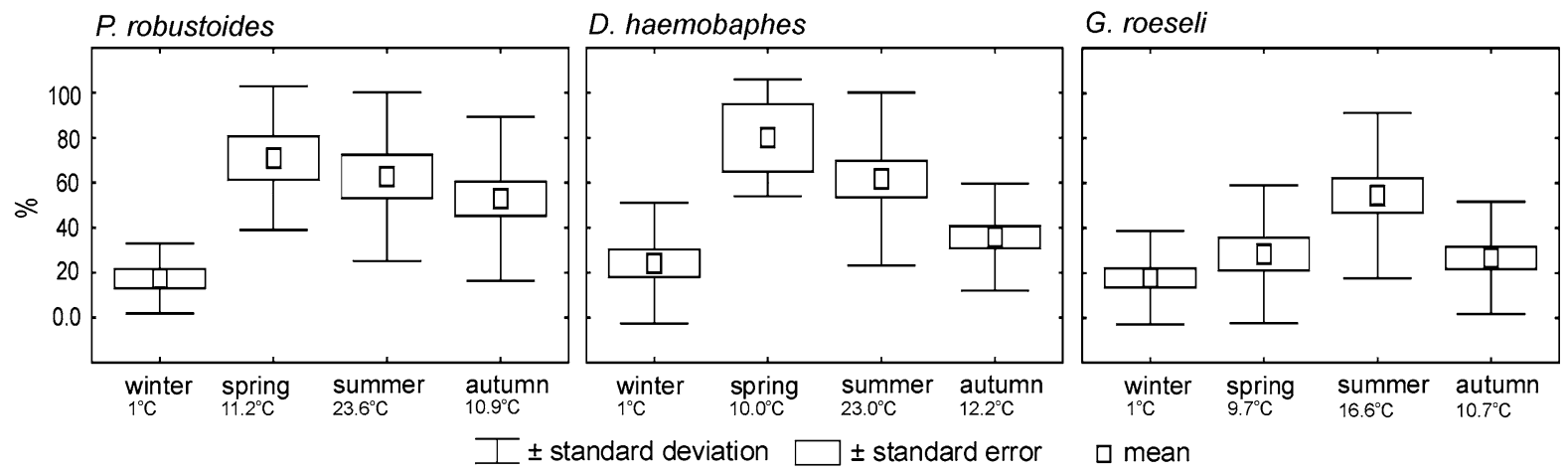

Fig. 3 Average percentage of animal tissue in the stomachs of Pontogammarus robustoides, Dikerogammarus haemobaphes and Gammarus roeseli during various seasons

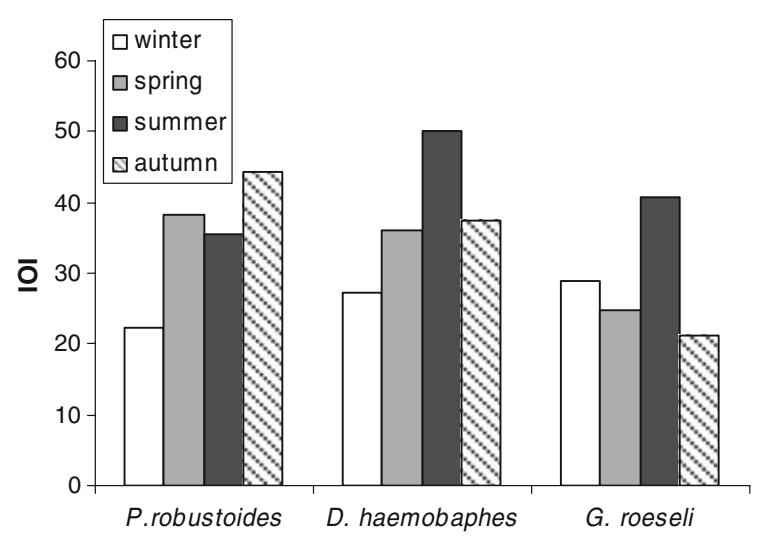

Fig. 4 Values of index of importance (IOI) of animal tissue in the diets of Pontogammarus robustoides, Dikerogammarus haemobaphes and Gammarus roeseli in various seasons

A similar phenomenon was observed when applying the index of importance (IOI) to the data. This index takes frequency into account (Fig. 4).

Predation rate by sexes versus temperature

A significant positive relationship between the average predation rate of $G$. fossarum by D. villosus and the temperature was found for both males and females (Fig. 5). The slopes and intercepts of the regressions significantly deviated from $0(P<0.05)$, meaning that feeding rate and temperature were significantly related for males as well as females.

$\ln \left(\frac{p_{\mathrm{m}}}{1-p_{\mathrm{m}}}\right)=0.14 \cdot$ TEMP -2.0 $\ln \left(\frac{p_{\mathrm{f}}}{1-p_{\mathrm{f}}}\right)=0.14 \cdot$ TEMP -3.8

where $p_{\mathrm{m}}$ and $p_{\mathrm{f}}$ are the predation rates by males and females, respectively.

The intercepts differed significantly between males and females $(P<0.1$, two-sided confidence interval), whereas no significant differences were found for the slopes $(P>0.9$, two-sided confidence interval). This implies that the slope dependency of the temperature and feeding rate did not differ significantly between males and females. However, the basic level of feeding was significantly higher for males than for females at any given temperature. Body size distribution did not differ significantly between the animals of the same sex used in the temperature tests (Mann-Whitney $\mathrm{U}$ test; SPSS 18.0.1), which means that the increase in predation rate with increasing temperature is not due to differences in body sizes within the sexes used for the experiments.

\section{Mortality versus temperature}

Average daily mortality of $D$. villosus during the experiments at all temperatures together, was very low, viz. $0.5 \%$ (SD $0.5 \%$ ). Average daily mortality was highest at $30^{\circ} \mathrm{C}$, but still low (on average $1.4 \%$ ). The range of average values at the other temperatures was $0-0.6 \%$. Daily mortality of $G$. fossarum without D. villosus was clearly increased at $30^{\circ} \mathrm{C}$, with an average mortality of $15.2 \%$. The range of average values at the other temperatures was $0.3-4.2 \%$. 


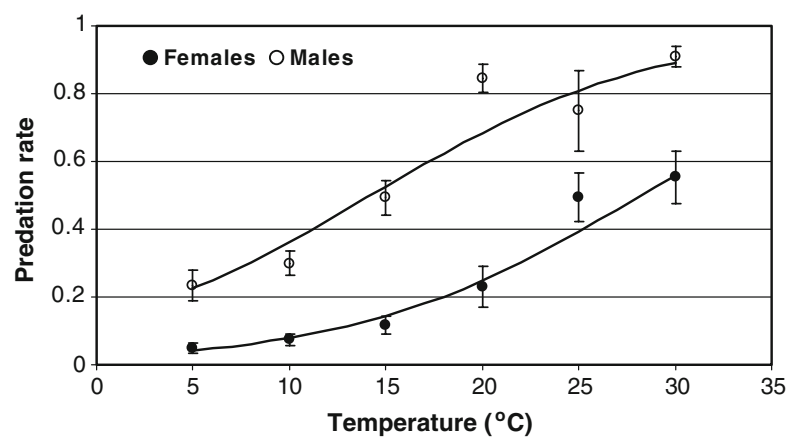

Fig. 5 Logistic fit of predation rate of Gammarus fossarum by Dikerogammarus villosus males (open circles) and females (filled circles) (average number of G. fossarum per D. villosus consumed per day). The error bars refer to \pm standard error of the mean due to the spread in the individual predation rates per specific ambient temperature in the experiments

\section{Allometric regressions of body parts involved in predation}

The sexes of $D$. villosus also significantly differed in terms of the slopes of the regressions of various measurements (Table 1) at alfa $=0.1$ (two-sided), viz., the diameter of antenna 1 , the length of antenna 2 , the diameter of antenna 2 and the lengths of propodus 1 and propodus 2 (Fig. 6). The slopes of the regressions of the length of antenna 1 and the length of the basal body of the mandible were not significantly different between the sexes. Differences in the measurements tended to be larger at larger body lengths of both sexes. Males grew to a larger size than the females, demonstrating a much stronger allometric growth in the body parts involved in predation.

Table 1 Slopes of the allometric regressions between body length and a number of species characteristics for males and females, and results of the test of significance between the male and female allometric regressions

\begin{tabular}{|c|c|c|c|}
\hline Species characteristic & Male & Female & Significance \\
\hline Length of antenna 1 & 0.357 & 0.348 & NS \\
\hline $\begin{array}{l}\text { Diameter of segment } 1 \\
\text { of antenna } 1\end{array}$ & 0.022 & 0.014 & $*$ \\
\hline Length of antenna 2 & 0.386 & 0.296 & $* *$ \\
\hline $\begin{array}{l}\text { Diameter of segment } 3 \\
\text { of antenna } 2\end{array}$ & 0.023 & 0.007 & $* * *$ \\
\hline Length of propodus gnathopod 1 & 0.092 & 0.061 & $* *$ \\
\hline Length of propodus gnathopod 2 & 0.123 & 0.083 & $* *$ \\
\hline $\begin{array}{l}\text { Length of basal body } \\
\text { of mandible }\end{array}$ & 0.061 & 0.050 & NS \\
\hline
\end{tabular}

$* P<0.05, * * P<0.01, * * * P<0.001, N S$ not significant

\section{Discussion}

The diet analyses of three non-indigenous invasive gammarideans revealed that animal food increases in spring and summer thus at increasing and higher temperatures. Our experiments show that higher temperatures stimulate $D$. villosus to increase the predation rate. At lower temperatures the animals become slow and prey less. However, at each temperature, there was a considerable variability in the predatory behaviour of the various specimens. Some specimens were regularly catching $G$. fossarum, eating them every day, while there were also individuals which did not eat any of these gammarideans during the whole experiment. Another source of variability was that some specimens of $D$. villosus were able to immediately catch their prey, while others could not, in spite of attempts, because G. fossarum were swimming around out of reach of the antennae of $D$. villosus, or because they kept to the rear of $D$. villosus, delaying the time that the latter could catch them. Furthermore, some specimens moulted during the experiments, and in this state they made few or no attempts to prey on G. fossarum. In spite of this variability, there was a significantly positive trend demonstrating that $D$. villosus increase their predation efficiency with increasing temperatures, even up to $30^{\circ} \mathrm{C}$. The low figures for daily mortality of $G$. fossarum hardly influenced the predation rate values, because they are negligible compared to the losses by predation at all temperatures except $30^{\circ} \mathrm{C}$.

The upper temperature tolerance for pleopod activity of D. villosus was about $31^{\circ} \mathrm{C}$, as its pleopod 

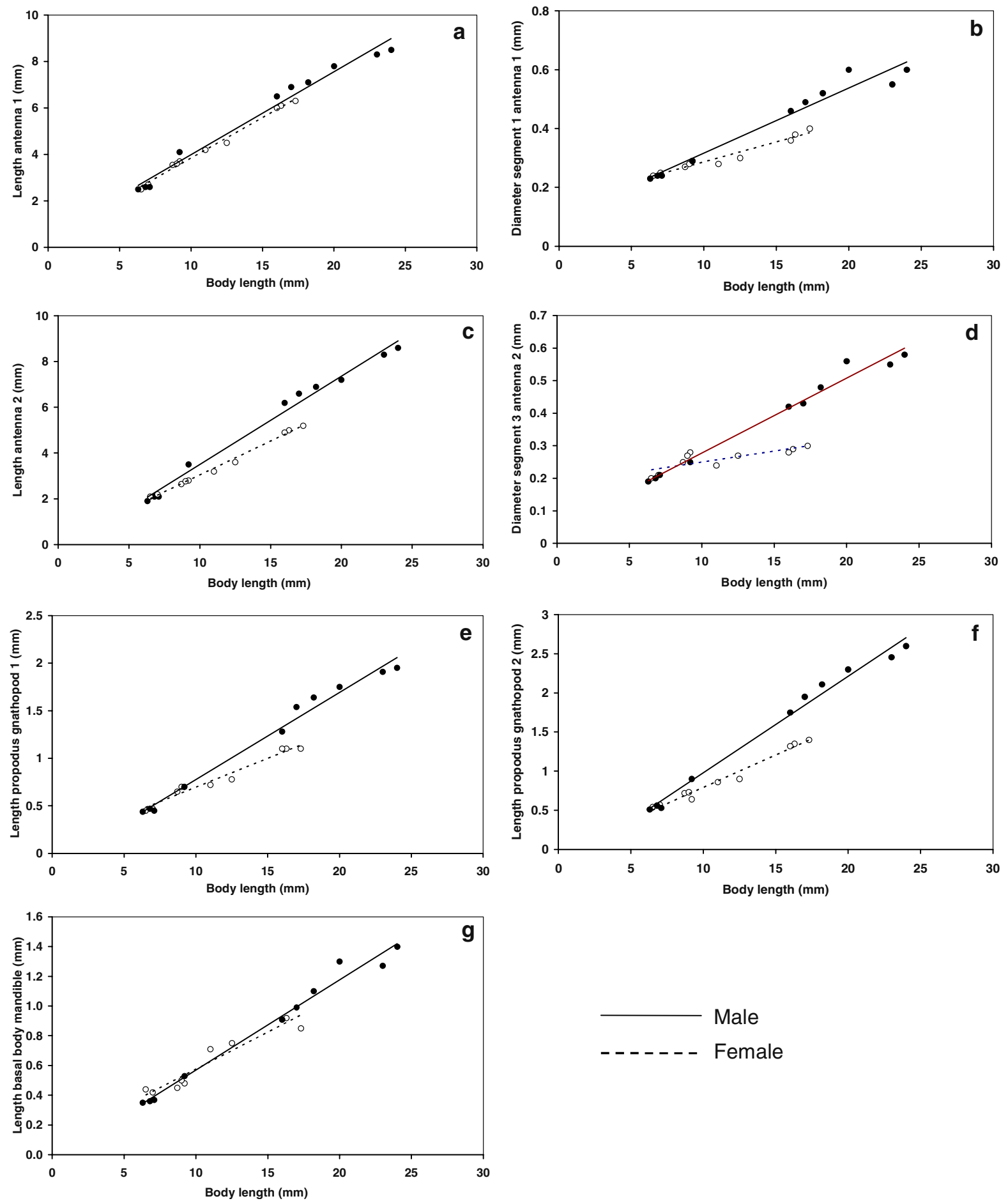

Fig. 6 Measurements of body parts of Dikerogammarus villosus involved in predatory feeding (see Fig. 2 for the parts measured) in relation to sex and body length (filled circles; females open circles) 
activity increased up to this temperature, whereas pleopod activity decreased quickly above $31^{\circ} \mathrm{C}$, indicating a tolerance limit. The upper temperature tolerance for pleopod activity of G. fossarum is $29^{\circ} \mathrm{C}$ (Wijnhoven et al. 2003a, b). This means that the increased mortality at $30^{\circ} \mathrm{C}$ may have been caused by suboptimal conditions for G. fossarum, which may also have contributed to the higher predation rate by D. villosus at that temperature.

The experiments comparing the predation rates between the two sexes showed the same trend for both sexes, but the average predation rates for the females were always lower than those for the males, across the temperature range. This means that sexrelated morphology may be important in terms of predation rate.

Although the mouthparts of $D$. villosus were studied by Mayer et al. (2008), they did not distinguish between males and females. They concluded from their extensive study that the mouthparts of this species show no particular specialisation for carnivory and predation, although the well-developed incisors are able to kill prey. The mouthparts also allow other modes of feeding, as was also demonstrated by Platvoet et al. (2006, 2009b). Kinzler and Maier (2003), who did predation experiments with D. villosus on G. fossarum, at $18^{\circ} \mathrm{C}$ found that males of $D$. villosus consumed more G. fossarum than the females did. In our study we found a difference between males and females with respect to predation rate, with males showing a higher predation rate over the whole temperature range tested. Allometric relationships of body parts involved in prey catching and holding differ between the sexes, with differences becoming larger at larger body sizes. The measurements of the body parts involved in detecting (first antennae) and processing (mouth parts), however, showed no difference between the sexes. Differences in allometry may explain why the predatory impact at the start of an invasion is more evident than later on. Invasive species in their newly invaded area are often released from predators and/or competitors and/or meet abundant suitable food such as animal prey, allowing them to grow faster and larger than in the area of origin. D. villosus is the largest gammaridean species in the area, reaching a size of up to $30 \mathrm{~mm}$ in the Rhine delta area, which is $6 \mathrm{~mm}$ larger than recorded in the River Danube (Platvoet 2007). In a study of a Danube population of D. villosus, Pöckl
(2009) found no males larger than $22 \mathrm{~mm}$ and no females larger than $18 \mathrm{~mm}$. D. villosus in the Rhine delta is thus much larger than recorded in the Danube from where it originated, although Nesemann et al. (1995) also mention $30 \mathrm{~mm}$ as the maximum size of D. villosus in its native area. This means that the predatory impact of $D$. villosus is determined by local and seasonal conditions determining increasing allometric growth differences between both sexes, including temperature and food availability. Felten et al. (2008b) carried out a study on the diet of G. fossarum in streams, which indicated its main role as collector and shredder. However, animal food was taken up by the larger specimens $(6-8 \mathrm{~mm})$ and was evident in submersed root and bryophyte but not in detrital pool habitats. Unfortunately they made no distinction between females and males, because the size difference can have caused this difference in predatory behaviour in relation to sex-related allometric growth. This approach can further elucidate such differences in diet and the mechanisms causing this difference.

\section{Conclusions}

The predatory behaviour of D. villosus is influenced by various factors, a main factor being the water temperature. Predation rate increased with increasing temperature over a temperature range of $5-30^{\circ} \mathrm{C}$. Perhaps this is a characteristic of more invasive gammaridean species, as we found that the food of the three other invasive species we analysed contained more animal prey in spring and summer than in wintertime. Males, which can grow larger than females were significantly more predatory than females indicating a sex-dependent predatory behaviour. We found a relation with the allometric growth of body parts involved in feeding, with the size of these body parts increasing faster during growth in males than the same body parts did in females.

These findings provide new information on the mechanisms and conditions of the predatory impact of gammaridean invasive species. We also know that size is important for the reproductive capacity of these gammarideans. When gammarideans are released from predation and find numerous easy preys in the areas they invade, their growth will make them more predaceous, as allometric growth of body parts involved in feeding allows them to feed on stronger 
prey, including relatives. This leads to the exclusion of competitors (intra- and interguild predation), particularly by males. Greater food availability under these conditions may accelerate growth and lead to higher densities through increased reproduction by females. Gammarideans seem to be all omnivores with a difference in sex and species specific predation abilities and intensities. Differences in predation rate, body size and allometric growth of body parts of both sexes involved should be studied also in other gammaridean species, native as well as invasive to predict their impact and competitive capacity.

Open Access This article is distributed under the terms of the Creative Commons Attribution Noncommercial License which permits any noncommercial use, distribution, and reproduction in any medium, provided the original author(s) and source are credited.

\section{References}

Bij de Vaate A, Jazdzewski K, Ketelaars HAM et al (2002) Geographical patterns in range extension of Ponto-Caspian macroinvertebrate species in Europe. Can J Fish Aquat Sci 59:1159-1174

Casellato S, Visentin A, La Piana G (2007) The predatory impact of Dikerogammarus villosus on fish. Chapter 27. In: Gherardi F (ed) Biological invaders in inland waters: Profiles, distribution, and threats. Springer, Dordrecht, pp 495-506

Dermott R, Witt J, Um EM et al (1998) Distribution of the Ponto-Caspian amphipod Echinogammarus ischnus in the Great Lakes and replacement of native Gammarus fasciatus. J Great Lakes Res 24:442-452

Dick JTA (1996) Post-invasion amphipod communities of Lough Neagh, Northern Ireland: influences of habitat selection and mutual predation. J Anim Ecol 65:756-767

Dick JTA, Platvoet D (1996) Intraguild predation and species exclusion in amphipods: the interaction of behaviour, physiology and environment. Freshw Biol 36:375-383

Dick JTA, Platvoet D (2000) Invading predatory crustacean Dikerogammarus villosus eliminates both native and exotic species. Proc R Soc Lond B: Biol Sci 267:977-983

Dick JTA, Montgomery WI, Elwood RW (1993) Replacement of the indigenous amphipod Gammarus duebeni celticus by the introduced $G$. pulex: differential cannibalism and mutual predation. J Anim Ecol 62:79-88

Dick JTA, Elwood RW, Montgomery WI (1995) The behavioral basis of a species replacement: differential aggression and predation between the introduced Gammarus pulex and the native G. duebeni celticus (Amphipoda). Behav Ecol Sociobiol 37:393-398

Dick JTA, Montgomery WI, Elwood RW (1999) Intraguild predation may explain an amphipod replacement: evidence from laboratory populations. J Zool 149:463-468
Dick JTA, Platvoet D, Kelly DW (2002) Predatory impact of the freshwater invader Dikerogammarus villosus (Crustacea: Amphipoda). Can J Fish Aquat Sci 59:1078-1084

Everitt BS, Dunn G (2001) Applied multivariate data analysis, 2nd edn. Arnold, London

Felten V, Doledec S, Statzner B (2008a) Coexistence of an invasive and a native gammarid across an experimental flow gradient: flow-refuge use, -mortality, and leaf-litter decay. Fundam Appl Limnol 172:37-48

Felten V, Tixier G, Guérold F et al (2008b) Quantification of diet variability in a stream amphipod: implications for ecosystem functioning. Fundam Appl Limnol 170:303-313

Grabowski M, Konopacka A, Jazdzewski K et al (2006) Native gammarid species in retreat and invasion of aliens in the Vistula Lagoon (Baltic Sea, Poland). Helgol Mar Res 60:90-97

Grabowski M, Jazdzewski K, Konopacka A (2007) Alien Crustacea in Polish waters-Amphipoda. Aquat Inv 2:25-38

Grabowski M, Bacela K, Konopacka A et al (2009) Salinityrelated distribution of alien amphipods in rivers provides refugia for native species. Biol Invasions. doi:10.1007/ s10530-009-9502-8

Haas G, Brunke M, Streit B (2002) Fast turnover in dominance of exotic species in the Rhine River determines biodiversity and ecosystem function: an affair between amphipods and mussels. In: Leppäkoski E, Gollasch S, Olenin S (eds) Invasive aquatic species of Europe: distribution, impacts and management. Kluwer Academic Publishers, Dordrecht, pp 426-432

Holdich DM, Pöck1 M (2007) Invasive crustaceans in European inland waters. In: Gherardi F (ed) Biological invaders in inland waters: Profiles, distribution, and threats. Springer, Dordrecht, pp 29-76

Hynes HBN (1950) The food of freshwater sticklebacks (Gasterosteus aculeatus and Pygosteus pungitius), with a review of methods used in studies of the food of fishes. $\mathrm{J}$ Anim Ecol 19:36-58

Hyslop EJ (1980) Stomach contents analysis-a review of methods and their application. J Fish Biol 17:411-429

Jazdzewski K (1980) Range of some gammaridean species in European inland waters caused by human activity. Crust Suppl 6:84-107

Jazdzewski K, Konopacka A (2000) Immigration history and present distribution of alien crustaceans in Polish waters. In: Von Vaupel Klein JC, Schram FR (eds) The biodiversity crisis and crustacea. Fourth International Crustacean Congress, Amsterdam, July 1998, vol 2. A.A. Balkema Publisher Rotterdam Brookfield, pp 55-64

Jazdzewski K, Konopacka A (2002) Invasive Ponto-Caspian species in waters of the Vistula and Oder basins and the southern Baltic Sea. In: Leppäkoski E, Gollasch S, Olenin $\mathrm{S}$ (eds) Invasive aquatic species of Europe-distribution, impacts and management. Kluwer Academic Publishers, Dordrecht, pp 384-398

Jazdzewski K, Konopacka A, Grabowski M (2002) Four PontoCaspian and one American gammarid species (Crustacea, Amphipoda) recently invading Polish waters. Contrib Zool 71:115-122

Jazdzewski K, Konopacka A, Grabowski M (2004) Recent drastic changes in the gammarid fauna of the Vistula 
River deltaic system in Poland caused by alien invaders. Divers Distrib 10:81-88

Jazdzewski K, Konopacka A, Grabowski M (2005) Native and alien malacostracan Crustacea along the Polish Baltic Sea coast in the twentieth century. Oceanol Hydrobiol Stud 24(Suppl 1/2005):195-208

Kelly DW, Dick JTA (2005) Effects of environment and an introduced invertebrate species on the structure of benthic macroinvertebrate species at the catchment level. Arch Hydrobiol 164:69-88

Kelly DW, Dick JTA, Montgomery WI et al (2003) Differences in composition of macroinvertebrate communities with invasive and native Gammarus spp. (Crustacea: Amphipoda). Freshw Biol 48:306-315

Kelly DW, Bailey RJ, MacNeil C et al (2006) Invasion by the amphipod Gammarus pulex alters community composition of native freshwater macroinvertebrates. Divers Distrib 12: 525-534

Kestrup AM, Ricciardi A (2009) Environmental heterogeneity limits the local dominance of an invasive freshwater crustacean. Biol Invasions. doi:10.1007/s10530-009-9490-8

Kinzler W, Maier G (2003) Asymmetry in mutual predation: possible reason for the replacement of native gammarids by invasives. Arch Hydrobiol 157:473-481

Leuven RSEW, Van der Velde G, Baijens I et al (2009) The river Rhine: a global highway for dispersal of aquatic invasive species. Biol Invasions. doi:10.1007/s10530-009-9491-7

MacNeil C, Prenter J (2000) Differential microdistributions and interspecific interaction in coexisting native and introduced Gammarus spp. (Crustacea: Amphipoda). J Zool Soc London 251:377-384

MacNeil C, Prenter J, Briffa M et al (2004) The replacement of a native freshwater amphipod by an invader: roles for environmental degradation and intraguild predation. Can J Fish Aquat Sci 61:1627-1635

MacNeil C, Platvoet D, Dick JTA (2008) Potential roles for differential body size and microhabitat complexity in mediating biotic interactions within invasive freshwater amphipod assemblages. Fundam Appl Limnol 172:175-182

Marguillier S, Dehairs F, Van der Velde G (1998) Initial results on the trophic relationships based on Corophium curvispinum in the Rhine traced by stable isotopes. In: Nienhuis PH, Leuven RSEW, Ragas AMJ et al (eds) New concepts for sustainable management of river basins. Backhuys Publishers, Leiden, pp 171-177

Mayer G, Maier G, Maas A et al (2008) Mouthparts of the Ponto-Caspian invader Dikerogammarus villosus (Amphipoda: Pontogammaridae). J Crust Biol 28:1-15

Meyer A, Kaschek N, Meyer EI (2005) The effect of low flow and stream drying on the distribution and relative abundance of the alien amphipod, Echinogammarus berilloni (Catta, 1878) in a karstic stream system (Westphalia, Germany). Crustaceana 77:909-922

Monakov AB (2003) Feeding of freshwater invertebrates. Kenobi Productions, Ghent, Belgium

Nesemann H, Pöckl M, Wittmann M (1995) Distribution of epigean Malacostraca in the middle and upper (Danube Hungary, Austria, Germany). Miscnea Zool Hung 10: 49-68

Pinkster S, Smit H, Brandse-de Jong N (1977) The introduction of the alien amphipod Gammarus tigrinus Sexton, 1939 in
The Netherlands and its competition with indigenous species. Crust Suppl 4:91-107

Piscart C, Dick JTA, McCrisken D et al (2009) Environmental mediation of intraguild predation between the freshwater invader Gammarus pulex and the native $G$. duebeni celticus. Biol Invasions. doi:10.1007/s10530-009-9497-1

Platvoet D (2007) Dikerogammarus villosus (Sowinsky, 1894) an amphipod with a bite. The relation between morphology, behaviour, micro-distribution and impact of this invading crustacean. $\mathrm{PhD}$ thesis University of Amsterdam

Platvoet D, Dick JTA, Konijnendijk N et al (2006) Feeding on micro-algae in the invasive Ponto-Caspian amphipod $\mathrm{Di}$ kerogammarus villosus (Sowinsky, 1894). Aquat Ecol 40: 237-245

Platvoet D, Dick JTA, MacNeil C et al (2009a) Invaderinvader interactions in relation to environmental heterogeneity leads to zonation of two invasive amphipods, Dikerogammarus villosus (Sowinsky) and Gammarus tigrinus Sexton: amphipod pilot species project (AMPIS) report 6. Biol Invasions. doi:10.1007/s10530-009-9488-2

Platvoet D, Van der Velde G, Dick JTA et al (2009b) Flexible omnivory in Dikerogammarus villosus (Sowinsky, 1894) (Amphipoda). Amphipod pilot species project (AMPIS) report 5. Crustaceana 82:703-720

Pöckl M (2009) Success of the invasive Ponto-Caspian amphipod Dikerogammarus villosus by life history traits and reproductive capacity. Biol Invasions. doi:10.1007/ s10530-009-9485-5

Polis GA, Myers CA, Holt RD (1989) The ecology and evolution of intraguild predation: potential competitors that eat each other. Ann Rev Ecol Syst 20:297-330

Schmitz W (1960) Die Einbürgerung von Gammarus tigrinus Sexton auf dem europäischen Kontinent. Arch Hydrobiol 57:223-225

Van der Velde G, Rajagopal S, Muskó I et al (2000) Ecological impact of crustacean invaders. General considerations and examples from the Rhine River. In: Von Vaupel Klein JC, Schram FR (eds) The Biodiversity Crisis, Crustacea. 4th International Crustacean Congress, Amsterdam, July 1998 vol 2. A.A. Balkema Publishers, Rotterdam Brookfield, Crustacean Issues 12:3-33

Van der Velde G, Nagelkerken I, Rajagopal S (2002) Invasions by alien species in inland freshwater bodies in Western Europe: the Rhine Delta. In: Leppäkoski E, Gollasch S, Olenin $\mathrm{S}$ et al (eds) Invasive species of Europe: distribution, impacts and management. Kluwer Academic Publishers, Dordrecht, pp 360-372

Van der Velde G, Rajagopal S, Kuyper-Kollenaar $M$ et al (2006) Biological invasions: concepts to understand and predict a global threat. In: Bobbink R, Beltman B, Verhoeven JTA, Whigham DF (eds) Wetlands: functioning, biodiversity conservation and restoration. Springer-Verlag, Berlin Ecological Studies 191:61-90

Van Overdijk CDA, Grigorovich IA, Mabee T et al (2003) Microhabitat selection by the invasive amphipod Echinogammarus ischnus and native Gammarus fasciatus in laboratory experiments and in Lake Erie. Freshw Biol 48: $567-578$

Van Riel MC, Van der Velde G, Rajagopal S et al (2006) Trophic relationships in the Rhine food web during invasion and after establishment of the Ponto-Caspian 
invader Dikerogammarus villosus. Hydrobiologia 565: 39-58

Van Riel MC, Healy EP, Van der Velde G et al (2007) Interference competition among native and invader amphipods. Acta Oecol 31:282-289

Van Riel MC, van der Velde G, bij de Vaate A (2009) Interference competition between alien invasive gammaridean species. Biol Invasions. doi:10.1007/s10530-009-9486-4
Wijnhoven S, Van Riel MC, Van der Velde G (2003a) Exotic and indigenous freshwater gammarid species: physiological tolerance to water temperature in relation to ionic content of the water. Aquat Ecol 37:151-158

Wijnhoven S, Van Riel MC, Van der Velde G (2003b) Reply to comments on Wijnhoven et al. (2003). Aquat Ecol 37: 449-450 